\title{
EFEKTIVITAS PEMBERIAN PUPUK ORGANIK CAIR DARI TIGA JENIS REBUNG BAMBU TERHADAP PERTUMBUHAN TANAMAN TOMAT (Solanum lycopersicum Mill.)
}

\author{
Alfian Bagus Setiawan ${ }^{1 *}$, Yulianty ${ }^{2}$, Endang Nurcahyani ${ }^{3}$, Martha L. Lande ${ }^{4}$ \\ 1, 2, 3, 4 Jurusan Biologi, Fakultas MIPA, Universitas Lampung, Indonesia \\ *E-mail: alfian1727@gmail.com
}

Received: Oktober $3^{\text {th }}, 2019$. Accepted: November $2^{\text {nd }}, 2019$. Published: December $29^{\text {th }}, 2019$

\begin{abstract}
The purpose of the study was to find out the effect of the delivery of organic liquid bamboo shoots against the growth of tomato plants (Solanum lycopersifall Mill.) and know the best concentration for its growth. This study was conducted in January 2018 to February 2018. The research was conducted in an integrated field laboratory, the Faculty of Agriculture Lampung University and the Botanical Laboratory of the Faculty of Mathematics and Natural sciences. This research method uses complete random draft (RAL) with 16 treatments. Bamboo shoots of Betung (Dendrocalamus asper (Schult) Backer E. x Heyne), Bamboo redude Tali (a Gigantochloa Apus (Schulft. F.) Kurz.), and bamboo shoots of yellow (Bambusa Vulgaris) with a concentration of liquid organic fertilizer Each type of bamboo consist of 6 concentrations namely: control (0\%), 5\%, 10\%, 15\%, 20\%, and 25\%, performed a replay as much as 2 times. Data analysis using measures that are test homogenity using Levene test with 5\% level and test range (ANOVA). Results of the study showed the treatment of liquid organic fertilizer bamboo shoots with a concentration of $10 \%$ (A1B2) The best treatment of the plant height, the length of the roots, dry weight, the content of chlorophyll a and the content of chlorophyll B, but has no effect To the total chlorophyll content of tomato plants.
\end{abstract}

Keywords: Bamboo shoots, liquid organic fertilizer, tomatoes (Solanum lycopersiand Mill).

\begin{abstract}
Abstrak
Tujuan dari penelitian ini adalah untuk mengetahui efek dari pemberian pupuk organik cair rebung bambu terhadap pertumbuhan tanaman tomat (Solanum lycopersicum Mill.) dan mengetahui konsentrasi yang paling baik untuk pertumbuhannya. Penelitian ini telah dilaksanakan pada bulan Januari 2018 sampai bulan Februari 2018. Penelitian dilakukan di laboratorium lapang terpadu, Fakultas Pertanian Universitas Lampung dan laboratorium botani Fakultas Matematika dan Ilmu Pengetahuan Alam. Metode penelitian ini menggunakan Rancangan Acak Lengkap (RAL) dengan 16 perlakuan. Rebung Bambu Betung (Dendrocalamus asper (Schult) Backer e.x Heyne), rebung Bambu Tali (Gigantochloa apus (Schulft.f.) Kurz.), dan rebung Bambu Kuning (Bambusa Vulgaris) dengan konsentrasi pupuk organik cair masing-masing jenis bambu terdiri dari 6 konsentrasi yaitu : kontrol $(0 \%), 5 \%, 10 \%, 15 \%, 20 \%$, dan 25\%, dilakukan ulangan sebanyak 2 kali. Analisis data menggunakan langkah-langkah yaitu uji homogenitas menggunakan uji levene dengan taraf $5 \%$ dan uji ragam (ANOVA). Hasil penelitian menunjukkan perlakuan pupuk organik cair rebung bambu betung dengan konsentrasi 10\% (A1B2) perlakuan yang terbaik terhadap tinggi tanaman, panjang akar, berat kering, kandungan klorofil a dan kandungan klorofil b, namun tidak berpengaruh terhadap kandungan klorofil total tanaman tomat.
\end{abstract}

Kata Kunci: Rebung Bambu; Pupuk organik cair; Tomat (Solanum lycopersicum Mill). 


\section{PENDAHULUAN}

Tomat dapat ditanam di dataran rendah maupun dataran tinggi sebab tanaman tomat hanya dapat berumur sekitar 3- 4 bulan (Edi dan Bobihoe 2010). Tomat selain sayuran juga dikatakan buah karna kaya akan vitamin dan mineral (Marti 2012; Maong, Rorong, dan Fatimah 2016). Penggunaan buahnya semakin luas, karena selain dikonsumsi sebagai tomat segar dan bumbu masakan, dapat diolah sebagai bahan baku industri makanan seperti sari buah dan saus tomat (Wasonowati 2011; Choulillah F 2016). Oleh karena itu dari tahun ke tahun Indonesia selalu berusaha untuk meningkatkan produksi tomat (Abidin, Kardhinata, dan Husni 2014; Krisnawati, Darini, dan Darnawi 2019). Namun hingga tahun 2004 Indonesia masih mengimpor tomat sebanyak $8.192 .280 \mathrm{~kg}$ baik dalam bentuk buah segar maupun dalam bentuk olahan yang berasal dari berbagai Negara (Latifah, Ratnawati, dan Sugiyarto 2017). Sehingga saat ini yang sangat diperlukan di Indonesia pengolahan tanaman tomat yang efektif seperti pemberian pupuk yang memiliki unsur hara yang lengkap, agar dapat meningkatkan produksi tomat dan mengurangi kegiatan impor tomat (Setiawan 2019).

Rebung yang berasal dari tunas muda dari bamboo (Kasi, Suaedi, dan Angraeni 2018). Rebung pada umumnya dimanfaatkan di dalam kuliner atau makanan tradisonal masyarakat Indonesia (Darmajana dkk. 2019; Hadiyaniyah, t.t.). Rebung yang dikonsumsi di Indonesia antara lain jenis bambu betung (Dendrocalamus asper (Schult) Backer e.x Heyne), bambu legi (Gigantochloa atter) yang tumbuh di pulau Jawa dan lainnya (Puspaningrum dan Sumadewi, t.t.). Rebung juga dimanfaatkan sebagai pupuk tanaman karena memiliki hormon pertumbuhan seperti giberelin, auksin, sitokinin, dan inhibitor (Walida dkk. 2019). Penggunaan rebung sebagai pupuk cair sangatlah potensial sebagai penunjang pertumbuhan dari tanaman, karena pupuk ini dapat merangsang daun, tunas-tunas, batang, dan bunga dari tanaman tersebut agar cepat tumbuh (Setiawan 2019).

Penggunaan pupuk organik cair menggunakan rebung "bambu tabah" yang diberikan pada tanaman sawi menghasilkan hasil pertumbuhan yang lebih baik pada konsentrasi 5\% (Nathania, Sukewijaya, dan Sutari 2012). Pemberian pupuk organik cair dari rebung ini terbukti meningkatkan tinggi tanama, berat basah, berat kering, namun tidak meningkatkan jumlah daun (Rosmaiti Dan Juliandi 2016; Mudya 2019). Adapun pengaruh pemberian mol rebung bambu terhadap pertumbuhan bibit kelapa sawit menghasilkan bahwa konsentrasi $10 \%$ menghasilkan efek paling baik untuk meningkatkan tinggi tanaman, luas daun, bobot kering akar kelapa dari konsentrasi lainnya yang diberikan (Samosir 2014; Thana 2017). Hal 
tersebut selaras dengan penelitian sebelumnya mengenai rebung (Novalina dkk. 2019; Kasi, Suaedi, dan Angraeni 2018; Alam 2017; Febriantami dan Nusyirwan 2017), namun terhadap tanaman tomat belum pernah diteliti sebelumnya. Oleh karena itu penelitian bertujuan untuk mengetahui efek dari pemberian pupuk organik cair rebung bambu terhadap pertumbuhan tanaman tomat (Solanum lycopersicum Mill.) dan mengetahui konsentrasi yang paling baik untuk pertumbuhannya dan akan menggunakan tiga jenis rebung untuk dijadikan pupuk organik cair dan untuk mengetahui perbedaan dari ketiganya.

\section{METODE}

Penelitian ini dilaksanakan di Laboratorium Botani Jurusan Biologi Fakultas Matematika dan Ilmu Pengetahuan Alam dan Laboratorium Lapang Terpadu Fakultas Pertanian Universitas Lampung. Penelitian ini menggunakan rebung dari tiga jenis bambu : Bambu Betung (Dendrocalamus asper (Schult) Backer e.x Heyne), Bambu Tali (Gigantochloa apus (Schult.f.) Kurz), dan Bambu Kuning (Bambusa vulgaris Schard. ex J.C. Wendl), Tomat (Solanum lycopersicum Mill), air leri (cucian beras), gula merah, air, pupuk kandang dan tanah. Penelitian ini menggunakan peralatan berupa labu polybag, ember, sprayer, penggaris, Gelas ukur, Pengaduk, corong, saringan, pisau, karung, selang, botol, dan alat tulis. Penelitian ini menggunakan Rancangan Acak Lengkap (RAL) dengan menggunakan konsentrasi kontrol 0\%, 5\%, 10\%, 15\%, 20\%, dan 25\% disetiap 3 jenis bambu sehingga menghasilkan 16 perlakuan dan dilakukan pengulangan sebanyak 2 kali.

Pembuatan larutan stok, rebung dari tiga jenis bambu masing masing sebanyak $1,5 \mathrm{~kg}$ di blender hingga halus, lalu ditaruh di ember masing-masing. Kemudian siapkan air leri (cucian beras) sebanyak 2,5 liter tiap embernya dan beri Gula merah sebanyak 150 gram. Kemudian rebung di campur dengan air leri dan gula merah di dalam ember dan di tutup dan diamkan selama 14 hari hingga terjadinya fermentasi terhadap pupuk (Eva, 2016). Penyiapan Media Tanam, media tanam berupa campuran antara tanah dan pupuk kandang yang sudah disterilisasikan dengan perbandingan 2 :1 antara tanah dan pupuk kandangnya dimasukkan ke dalam polybag ukuran besar $5 \mathrm{~kg}$. Polybag diisi media tanam hingga tersisa $5 \mathrm{~cm}$ dari permukaan polybag. Penyemaian tanaman tomat, benih tomat disemai terlebih dahulu hingga 2 minggu, diperlukan wadah semai yang berfungsi sebagai tempat untuk menyemai benih. Wadah semai diisi media tanam sedalam 0,5 - $1 \mathrm{~cm}$ semaian kemudian ditutup dengan tanah secara rata. Semaian disiram setiap hari menggunakan sprayer.

Penanaman tanaman tomat, tanaman tomat yang dipilih adalah tanaman yang memiliki ukuran sama dengan jumlah 4 daun atau tanaman berumur 2 minggu. Tanaman tomat dipindahkan ke polybag berukuran $5 \mathrm{~kg}$ yang telah diisi media tanam, tanaman ditanam sedalam $1 \mathrm{~cm}$ dari permukaan tanah lalu disiram dan tanaman diberi perlakuan setelah 1 minggu setelah pindah tanam hal ini 
dilakukan agar tanaman tomat dapat melakukan proses adaptasi terlebih dahulu. Parameter pengamatan, parameter yang di amati adalah tinggi tanaman, panjang akar, berat kering dan kandungan klorofil.

\section{HASIL DAN PEMBAHASAN}

Pemberian pupuk organik cair berpengaruh terhadap tinggi tanaman tomat. Rata-rata tinggi tanaman tomat disajikan dalam tabel 1.

Tabel 1. Rata-rata Tinggi Tanaman Tomat Setelah diberikan Pupuk Organik Cair Tiga Jenis Rebung Hari setelah Tanam (HST)

\begin{tabular}{ccccc}
\hline Jenis Rebung/konsentrasi & 28 HST & 32 HST & 36 HST & 40 HST \\
\hline A0B0 & $5.5 \mathrm{a}$ & $7.0 \mathrm{a}$ & $11.5 \mathrm{a}$ & $15.7 \mathrm{a}$ \\
A1B1 & $7.4 \mathrm{~b}$ & $9.6 \mathrm{bc}$ & $16.6 \mathrm{~b}$ & $21.0 \mathrm{~b}$ \\
A2B1 & $7.4 \mathrm{~b}$ & $10.9 \mathrm{~d}$ & $15.5 \mathrm{c}$ & $19.1 \mathrm{c}$ \\
A3B1 & $8.2 \mathrm{c}$ & $11.9 \mathrm{ef}$ & $18.1 \mathrm{~d}$ & $22.9 \mathrm{~d}$ \\
A1B2 & $13.1 \mathrm{~d}$ & $18.6 \mathrm{~g}$ & $28.8 \mathrm{e}$ & $35.9 \mathrm{e}$ \\
A2B2 & $12.4 \mathrm{e}$ & $17.8 \mathrm{~h}$ & $27.3 \mathrm{f}$ & $33.1 \mathrm{f}$ \\
A3B2 & $11.6 \mathrm{f}$ & $17.3 \mathrm{~h}$ & $25.9 \mathrm{~g}$ & $31.0 \mathrm{~g}$ \\
A1B3 & $10.4 \mathrm{~g}$ & $16.5 \mathrm{i}$ & $24.6 \mathrm{~h}$ & $28.0 \mathrm{~h}$ \\
A2B3 & $10.1 \mathrm{~g}$ & $16.1 \mathrm{ij}$ & $23.2 \mathrm{i}$ & $27.0 \mathrm{i}$ \\
A3B3 & $9.3 \mathrm{~h}$ & $15.6 \mathrm{j}$ & $23.5 \mathrm{i}$ & $28.6 \mathrm{~h}$ \\
A1B4 & $8.4 \mathrm{c}$ & $11.8 \mathrm{f}$ & $18.6 \mathrm{~d}$ & $23.6 \mathrm{j}$ \\
A2B4 & $8.7 \mathrm{c}$ & $12.7 \mathrm{k}$ & $19.5 \mathrm{j}$ & $25.3 \mathrm{k}$ \\
A3B4 & $8.3 \mathrm{c}$ & $12.4 \mathrm{ek}$ & $19.3 \mathrm{j}$ & $24.8 \mathrm{k}$ \\
A1B5 & $7.0 \mathrm{i}$ & $9.4 \mathrm{c}$ & $14.3 \mathrm{k}$ & $17.8 \mathrm{l}$ \\
A2B5 & $6.2 \mathrm{i}$ & $8.3 \mathrm{l}$ & $12.2 \mathrm{a}$ & $16.0 \mathrm{a}$ \\
A3B5 & $7.1 \mathrm{i}$ & $10.1 \mathrm{~b}$ & $14.6 \mathrm{k}$ & $18.6 \mathrm{c}$ \\
\hline
\end{tabular}

Keterangan : angka yang diikuti huruf yang sama pada kolom yang sama menunjukkan tidak berbeda $\mathrm{A} 0=$ Kontrol nyata berdasarkan hasil analisis ragam dan uji BNT pada taraf 5\%

A1 = Pupuk organik cair dari bambu betung

A2 $=$ Pupuk organik cair dari bambu tali

A3 = Pupuk organik cair dari bambu kuning

B1-B5 = Konsentrasi secara berurut $5 \%, 10 \%, 15 \%, 20 \%$, dan $25 \%$

Tabel 1 terlihat bahwa tinggi tanaman tomat yang diberikan pupuk organik cair dari tiga jenis rebung menunjukan adanya perbedaan pada masing masing konsentrasi. Perlakuan Bambu betung dengan konsentrasi 10\% (A1B2) memberikan hasil yang tertinggi terhadap tinggi tanaman tomat baik pada 28, 32, 36, dan 40 hari setelah tanam. Hasil perlakuan bambu betung dengan konsentrasi 10\% (A1B2) mempunyai rata-rata nilai tertinggi yaitu $35,9 \mathrm{~cm}$ pada 40 hari setelah tanam. Hasil yang terendah terdapat pada perlakuan A0B0 (kontrol) dengan rata- rata yaitu 15,7 cm pada 40 hari setelah tanam. Berdasarkan hasil analisis ragam (ANOVA) menunjukkan pemberian pupuk organik cair tiga 
jenis rebung berpengaruh terhadap panjang akar tanaman tomat. Rata-rata panjang akar tanaman tomat akan disajikan dalam bentuk Tabel 2 sebagai berikut.

Tabel. 2 Rata-Rata Panjang Akar Tanaman Tomat Setelah Diberikan Pupuk Organik Cair Tiga Jenis Rebung

\begin{tabular}{ccc}
\hline Perlakuan & Konsentrasi \% & Panjang Akar \\
\hline A0 & B0 & $7.4 \mathrm{~g}$ \\
A1 & B1 & $11.8 \mathrm{bc}$ \\
A1 & B2 & $15.2 \mathrm{a}$ \\
A1 & B3 & $11.6 \mathrm{bcd}$ \\
A1 & B4 & $10.6 \mathrm{cde}$ \\
A1 & B5 & $9.6 \mathrm{ef}$ \\
A2 & B1 & $10.9 \mathrm{cde}$ \\
A2 & B2 & $14.9 \mathrm{a}$ \\
A2 & B3 & $10.9 \mathrm{cde}$ \\
A2 & B4 & $10.3 \mathrm{de}$ \\
A2 & B5 & $9.8 \mathrm{ef}$ \\
A3 & B1 & $8.9 \mathrm{f}$ \\
A3 & B2 & $12.7 \mathrm{~b}$ \\
A3 & B3 & $10.6 \mathrm{cde}$ \\
A3 & B4 & $10.2 \mathrm{ef}$ \\
A3 & B5 & $8.9 \mathrm{f}$ \\
\hline
\end{tabular}

Keterangan : Angka yang diikuti huruf yang sama pada kolom yang sama menunjukkan tidak berbeda nyata berdasarkan hasil analisis ragam dan uji BNT pada taraf 5\%

A $0=$ Kontrol

A1 = Pupuk organik cair dari bambu betung

A2 $=$ Pupuk organik cair dari bambu tali

A3 = Pupuk organik cair dari bambu kuning

B1-B5 = Konsentrasi secara berurut 5\%, 10\%, 15\%, 20\%, dan 25\%

Tabel 2 menunjukan pengaruh pupuk organik cair terhadap panjang akar tanaman tomat, perbedaan terlihat dari setiap perlakuannya. Bambu betung dengan konsentrasi 10\% (A1B2) merupakan perlakuan yang terbaik terhadap panjang akar tanaman tomat, sedangkan perlakuan yang terendah adalah A0B0 (kontrol). Berdasarkan hasil analisis ragam (ANOVA) menunjukkan pemberian pupuk organik cair dari tiga jenis rebung berpengaruh terhadap berat kering dari tanaman tomat. Berikut rata - rata berat kering tanaman tomat akan disajikan dalam Tabel 3 sebagai berikut. 
Tabel 3. Rata-Rata Berat Kering Tanaman Tomat Setelah Diberikan Pupuk Organik Cair Tiga Jenis Rebung

\begin{tabular}{ccc}
\hline Perlakuan & Konsentrasi $\%$ & Berat Kering \\
\hline A0 & B0 & $12.3 \mathrm{i}$ \\
A1 & B1 & $20.6 \mathrm{c}$ \\
A1 & B2 & $24.6 \mathrm{a}$ \\
A1 & B3 & $19.5 \mathrm{de}$ \\
A1 & B4 & $19 \mathrm{e}$ \\
A1 & B5 & $14.3 \mathrm{~g}$ \\
A2 & B1 & $20.4 \mathrm{~cd}$ \\
A2 & B2 & $22.2 \mathrm{~b}$ \\
A2 & B3 & $20.2 \mathrm{~cd}$ \\
A2 & B4 & $19.2 \mathrm{e}$ \\
A2 & B5 & $13.7 \mathrm{gh}$ \\
A3 & B1 & $16.8 \mathrm{f}$ \\
A3 & B2 & $20.9 \mathrm{c}$ \\
A3 & B3 & $19.2 \mathrm{e}$ \\
A3 & B4 & $18.8 \mathrm{e}$ \\
A3 & B5 & $13.0 \mathrm{hi}$
\end{tabular}

Keterangan : Angka yang diikuti huruf yang sama pada kolom yang sama menunjukkan tidak berbeda nyata berdasarkan hasil analisis ragam dan uji BNT pada taraf 5\%

A $0=$ Kontrol

A1 = Pupuk organik cair dari bambu betung

A2 $=$ Pupuk organik cair dari bambu tali

A3 = Pupuk organik cair dari bambu kuning

B1-B5 = Konsentrasi secara berurut 5\%, 10\%, 15\%, 20\%, dan 25\%

Tabel 3 menunjukkan bahwa tanaman tomat yang diberikan pupuk organik cair dari tiga jenis rebung bambu berpengaruh terhadap berat kering tanaman tomat. Perlakuan terbaik dalam meningkatkan berat kering tumbuhan tomat adalah A1B2 (pupuk bambu betung dengan konsentrasi 10\%) dengan rata-rata 24.6 gr. Hal ini berbeda disbanding dengan kontrol (A0B0) yang menunjukkan rata-rata 12.3 gr. Kandungan klorofil yang diuji meliputi kandungan klorofil a, kandungan klorofil b, dan kandungan klorofil total. Hasil uji ANOVA $(0,05)$ untuk kandungan klorofil a, kandungan klorofil b dan kandungan klorofil total, diketahui bahwa pemberian pupuk organik cair dari tiga jenis rebung memberikan pengaruh nyata terhadap kandungan klorofil a, dan kandungan klorofil b, sedangkan klorofil total tanaman tomat tidak memberikan pengaruh yang nyata. Rata-rata kandungan klorofil a, kandungan klorofil b, dan kandungan klorofil total dapat dilihat dalam tabel sebagai berikut. 
Tabel 4. Rata-Rata Klorofil A, Klorofil B Dan Klorofil Total Tanaman Tomat Setelah Diberikan Pupuk Organik Cair Tiga Jenis Rebung

\begin{tabular}{cccc}
\hline $\begin{array}{c}\text { Jenis } \\
\text { Rebung/konsentrasi }\end{array}$ & Klorofil a & Klorofil b & Klorofil total \\
A0B0 & $1.7 \mathrm{Bbcd}$ & $1.1 \mathrm{bc}$ & 0.8 \\
A1B1 & $2.2 \mathrm{a}$ & $1.4 \mathrm{a}$ & 1.0 \\
A2B1 & $1.5 \mathrm{~d}$ & $1.0 \mathrm{c}$ & 0.8 \\
A3B1 & $1.8 \mathrm{abcd}$ & $1.2 \mathrm{abc}$ & 0.9 \\
A1B2 & $2.2 \mathrm{a}$ & $1.4 \mathrm{a}$ & 1.0 \\
A2B2 & $2.0 \mathrm{abc}$ & $1.3 \mathrm{ab}$ & 0.9 \\
A3B2 & $2.1 \mathrm{ab}$ & $1.3 \mathrm{ab}$ & 1.0 \\
A1B3 & $2.1 \mathrm{ab}$ & $1.4 \mathrm{a}$ & 1.0 \\
A2B3 & $2.1 \mathrm{ab}$ & $1.3 \mathrm{ab}$ & 1.0 \\
A3B3 & $1.9 \mathrm{abcd}$ & $1.3 \mathrm{ab}$ & 1.0 \\
A1B4 & $2.2 \mathrm{a}$ & $1.4 \mathrm{a}$ & 1.0 \\
A2B4 & $1.5 \mathrm{~d}$ & $1.0 \mathrm{c}$ & 0.8 \\
A3B4 & $1.7 \mathrm{bcd}$ & $1.1 \mathrm{bc}$ & 0.8 \\
A1B5 & $1.6 \mathrm{~cd}$ & $1.1 \mathrm{bc}$ & 0.8 \\
A2B5 & $1.7 \mathrm{bcd}$ & $1.1 \mathrm{bc}$ & 0.8 \\
A3B5 & $1.5 \mathrm{~d}$ & $1.0 \mathrm{c}$ & 0.8
\end{tabular}

Keterangan : Angka yang diikuti huruf yang sama pada kolom yang sama menunjukkan tidak berbeda nyata berdasarkan hasil analisis ragam dan uji BNT pada taraf 5\%

A $0=$ Kontrol

A1 = Pupuk organik cair dari bambu betung

A2 $=$ Pupuk organik cair dari bambu tali

A3 = Pupuk organik cair dari bambu kuning

B1-B5 = Konsentrasi secara berurut $5 \%, 10 \%, 15 \%, 20 \%$, dan $25 \%$.

Tabel 5 menunjukan kandungan klorofil a tertinggi dengan nilai rata-rata 2.2 dihasilkan dari perlakuan bambu betung (A1) dengan konsentrasi 5\%, $10 \%$ dan $20 \%$. Sedangkan kandungan klorofil b tertinggi dengan nilai rata-rata 1.4 dihasilkan dari perlakuan bambu betung (A1) dengan konsentrasi 5\%, 10\%, 15\% dan 20\%. Namun kandungan klorofil total tidak berpengaruh.

Berdasarkan penelitian yang dilakukan, pupuk organik cair dari tiga jenis rebung bambu memberikan pengaruh terhadap tinggi tanaman tomat. Perlakuan terbaik adalah pupuk bambu betung dengan konsentrasil 10\% (A1B2) dibandingkan dengan perlakuan yang lainnya. Rebung bambu yang masih berbentuk tunas memiliki zat pengatur tumbuh yang tinggi seperti auksin dan giberelin yang dapat berfungsi untuk merespon tinggi tanaman dan besar tanaman. Sehingga rebung dapat menjadi pupuk yang baik untuk tumbuhan lain sebagai media menyuplai zat pengatur tumbuh. Auksin diberikan pada sekelompok senyawa kimia yang memiliki fungsi utama mendorong pemanjangan kuncup yang sedang berkembang. 
Beberapa auksin dihasikan secara alami oleh tumbuhan, misalnya IAA (indoleacetic acid), PAA (Phenylacetic acid), 4-chloroIAA dan IBA (indolebutyr icacid) dan beberapa lainnya merupakan auksin sintetik, misalnya NAA (napthalene acetic acid), 2,4 D (2,4 dichlorophenoxyacetic acid) dan MCPA (2-methyl-4 chlor ophenoxyacetic acid). Beberapa proses bekerjanya auksin pada tumbuhan adalah sebagai berikut: pertama auksin turut serta dalam reaksi molekuler. Auksin bekerja sepertinya bekerjanya koenzim dalam pertumbuhan tanaman.Kedua auxin mempengaruhi enzim. Auksin bekerja sebagai zat pelindung bagi enzim dari inaktivasi.Auksin mempengaruhi DNA sehingga aktif dalam sintesis protein. Ketiga auksin mempengaruhi tekanan osmotik tumbuhan. Auksin akan menaikkan tekanan osmotik tumbuhan sehingga akan menaikkan tinggi tumbuhan tersebut (Lestari 2011).

Giberelin (GA) merupakan hormon yang dapat ditemukan pada semua seluruh hidup tanaman. Hormon ini mempengaruhi perkecambahan biji, perpanjangan batang, induksi bunga, pengembangan anter, perkembangan biji, dan pertumbuhan batang. Selain itu, hormon ini juga berperan dalam respon menanggapi rangsang dari melalui regulasi fisiologis berkaitan dengan mekanisme biosntesis GA. Giberelin pada tumbuhan dapat ditemukan dalam dua fase utama yaitu giberelin aktif (GA Bioaktif) dan giberelin nonaktif (Gani dan Elvi Rusmiyanto P Wardoyo 2017). Pemberian pupuk organik cair dapat menambah tinggi tanaman tomat ini diperkirakan bahwa pupuk organik cair dapat menyebabkan terpacunya sel di ujung batang yang mengalami pembelahan sel, dan perbesaran sel terutama di sel meristematis. Hal ini sesuai (Parman 2007) yang mengatakan bahwa pembelahan secara antiklinal dan periklinal dan perbesaran sel meristematis di ujung batang, meskipun laju kecepatannya tidak sama. Lakitan (1996) mengatakan bahwa pemberian pupuk organik cair yang mengandung unsur $\mathrm{N}, \mathrm{P}, \mathrm{K}, \mathrm{Mg}$ dan $\mathrm{Ca}$ akan menyebabkan terpacunya sintesis dam pembelahan dinding sel secara antiklinal sehingga akan mempercepat pertambahan tinggi tanaman.

Perbedaan laju pertumbuhan dan aktivitas jaringan meristematis yang tidak sama, dapat menyebabkan perbedaan laju pembentukan yang tidak sama pada organ yang terbentuk. Selain itu pemberian pupuk organik cair yang lengkap kandungan haranya akan menyebabkan laju pertumbuhan yang berbeda (Duaja 2012; Ignatius dan Riduan 2014; Aryani dan Musbik 2018). Berdasarkan hasil penelitian menunjukkan pemberian pupuk organik cair dari tiga jenis rebung bambu berpengaruh terhadap panjang akar tumbuhan tomat dengan perlakuan A1B2 (pupuk bambu betung dengan konsentrasi 10\%) menunjukan hasil paling terbaik untuk 
panjang akar tumbuhan tomat. Semakin panjang akar suatu tumbuhan maka semakin luas juga daerah asimilasinya sehingga tumbuhan yang memiliki panjang akar yang baik maka tumbuhan itu juga tumbuh dengan baik.

Pertumbuhan tanaman diawali dengan perkecambahan. Selanjutnya, daun akan tumbuh bersamaan dengan tumbuhnya akar. Daun berperan sebagai tempat produksi makanan yang akan disebar ke seluruh tubuh tanaman hingga akar. Akar juga akan menyerap nutrien di tanah dan menyalurkannya hingga daun (Dwiratna 2017). Berdasarkan hasil penelitian pupuk organik cair dari tiga jenis rebung bambu berpengaruh terhadap berat kering tanaman tomat dengan perlakuan yang terbaik adalah pupuk bambu betung dengan konsentrasi 10\% (A1B2) dibanding dengan jenis bambu lainnya. Gardner (1991) mengatakan bahwa berat kering tumbuhan adalah keseimbangan antara pengambilan $\mathrm{CO}_{2}$ (fotosintesis) dan pengeluaran $\mathrm{CO}_{2}$ (respirasi). Apabila respirasi lebih besar dibanding fotosintesis tumbuhan itu akan berkurang berat keringnya. Pupuk organic cair mengandung unsur hara kalium dan kalsium yang akan meningkatkan pertumbuhan dan perkembangan akar lateral sehingga mempengaruhi kemampuantanaman kentang dalam menyerap air. Hal ini menyebabkan tanaman kentang dengan perlakuan berbeda akan menyerap air dengan jumlah yang berbeda-beda yang selanjutnya air akan menguap pada saat proses pengeringan. Kandungan klorofil pada tanaman dapat menjadi salah satu indikator pertumbuhan tanaman, kandungan klorofil yang tinggi menunjukkan tumbuhan tersebut memiliki daya hidup yang baik dikarenakan semakin tinggi klorofil semakin baik proses fotosintesisnya (Zulfiah dan Aisyah 2016). Selain itu, kandungan klorofil yang tidak berbeda nyata juga dipengaruhi oleh adanya persamaan penerimaan cahaya. Semakin tinggi intensitas cahaya yang diterima, maka kandungan klorofil akan semakin tinggi (Sihombing dan Aryawaty 2013; Buntoro, Rogomulyo, dan Trisnowati 2014).

Faktor utama pembentuk klorofil adalah nitrogen $(\mathrm{N})$. Unsur $\mathrm{N}$ merupakan unsur hara makro.Unsur ini diperlukan oleh tanaman dalam jumlah banyak. Unsur $\mathrm{N}$ diperlukan oleh tanaman, salah satunya sebagai penyusun klorofil. Tanaman yang kekurangan unsur $\mathrm{N}$ akan menunjukkan gejala antara lain klorosis pada daun. Tanaman tidak dapat menggunakan Nitrogen secara langsung. Gas Nitrogen tersebut harus difiksasi oleh bakteri menjadi amonia $\left(\mathrm{NH}_{3}\right)$ (Hendriyani dan Setiari 2009; Sudjana 2015). Faktor kandungan klorofil total yang tidak dipengaruhi oleh pupuk organik cair rebung bambu di duga kandungan kalium dan magnesiumnya sama dalam tiga jenis rebung), secara umum suku bambuseae memiliki 
Rebung berbentuk kerucut, kokoh dan terbungkus dalam kelopak daun yang rapat disertai bulu-bulu halus. Kandungan kimia yang terdapat pada rebung mentah per 100 gram yang dapat dimanfaatkan diantaranya air 91 gram/100 gram, fosfor 59 mg, kalsium 13 mg, kalium $533 \mathrm{mg}$. sehingga dapat diperkirakan bawah tiga jenis rebung tersebut memiliki kandungan yang tidak jauh berbeda. Kandungan tersebut adalah bahan dasar pembentukan klorofil. Pada data menunjukan tidak beda nyata hal ini dapat pula dikarenakan usia tanaman yang sama kandungan nitrogen didalam tanah yang sama, serta kandungan mineral di dalam unsur haranya yang sama adapun penelitian sebelumnya yang mengetakan tanah, udara dan air juga ikut mempengaruhi oembentukan klorofil (Subandi, Salam, dan Frasetya 2015; Hasidah dan Rousdy 2017).

\section{SIMPULAN DAN SARAN}

Berdasarkan hasil penelitian ini, dapat disimpulkan pemberian pupuk organik cair berpengaruh terhadap tinggi tanaman, panjang akar, berat kering, klorofil a dan klorofil b pada tanaman tomat, tetapi tidak mempengaruhi kandungan klorofil total. Pupuk organik cair (POC) rebung bambu betung dengan konsentrasi 10\% (A1B2) merupakan perlakuan yang terbaik dalam meningkatkan pertumbuhan tanaman tomat.

Saran terhadap penelitian lebih lanjut agak dapat dilakukan penelitian dengan jenis rebung lain dan indikator pengamatan lainnya seperti jumlah daun, jumlah bunga dan jumlah buah pada tanaman tomat.

\section{DAFTAR PUSTAKA}

Abidin, Ali Zainal, Emmy Harso Kardhinata, Dan Yusuf Husni. 2014. "Respons Pertumbuhan Dan Produksi Beberapa Varietas Tomat (Lycopersicum Esculentum L.) Dataran Rendah Terhadap Pemberian Pupuk Kandang Ayam.” Agroekoteknologi 2 (4).

Alam, Murid Haris Nurul. 2017. "Pengaruh Macam Dan Konsentrasi Pupuk Organik Cair Terhadap Tanaman Brokoli (Brassica Oleraceaevar. Italica).” University Of Muhammadiyah Malang.

Aryani, Ida, Dan Musbik Musbik. 2018. "Pengaruh Takaran Pupuk Organik Cair Terhadap Pertumbuhan Tanaman Sawi Caisim (Brassica Juncea L) Di Polibag." Prospek Agroteknologi 7 (1): 60-68.

Buntoro, Bagus Hari, Rohlan Rogomulyo, Dan Sri Trisnowati. 2014. "Pengaruh Takaran Pupuk Kandang Dan Intensitas Cahaya Terhadap Pertumbuhan Dan Hasil Temu Putih (Curcuma Zedoaria L.)." Vegetalika 3 (4): 29-39. 
Choulillah F, Riezqi. 2016. "Pertumbuhan Dan Hasil Tanaman Tomat (Solanum Lycopersicum L. Karst) Pada Berbagai Dosis Azolla (Azolla Microphylla) Dan Pupuk P."

Darmajana, Doddy A., Novianti Wulandari, Rima Kumalasari, Dan Ade Chandra Irwansyah. 2019. "Pengaruh Perbandingan Tepung Rebung (Dendrocalamus Asper) Dan Tepung Teriguterhadap Karakteristikkimia Dan Karakteristik Sensori Cookies." Jurnal Penelitian Pascapanen Pertanian 16 (1): 41-48.

Duaja, Wiekandyne. 2012. "Pengaruh Pupuk Urea, Pupuk Organik Padat Dan Cair Kotoran Ayam Terhadap Sifat Tanah, Pertumbuhan Dan Hasil Selada Keriting Di Tanah Inceptisol.” Jurnal Fakultas Pertanian 1 (4): 236-46.

Dwiratna, Sophia. 2017. "Penentuan Komposisi Media Tanam Terbaik Untuk Budidaya Selada Merah Menggunkana Sistem Autpot Modifikasi." Jurnal Pertanian Tropik (Indonesian Tropical Agriculture Journal) Accredited By Kemenristek Dikti No: 21/E/Kpt/2018 4 (3, Dec): 219-27.

Edi, Syafri, Dan Julistia Bobihoe. 2010. "Budidaya Tanaman Sayuran.” Jambi: Balai Pengkajian Teknologi Pertanian (Bptp) Jambi.

Febriantami, Astrice, Dan Nusyirwan Nusyirwan. 2017. "Pengaruh Pemberian Pupuk Organik Cair Dan Ekstrak Rebung Terhadap Pertumbuhan Dan Hasil Tanaman Kacangpanjang (Vignasinensisl.).” Jurnal Biosains 3 (2): 96-102.

Gani, Alia A., Dan Mukarlina Elvi Rusmiyanto P Wardoyo. 2017. "Profil Gc-Ms Dan Potensi Bioherbisida Ekstrak Metanol Daun Ketapang (Terminalia Catappa L.) Terhadap Gulma Maman Ungu (Cleome Rutidosperma Dc).” Protobiont 6 (2).

Hadiyaniyah, Yani Nurfitri. T.T. "Leksikon Makanan Tradisional Sunda Di Kabupaten Kuningan (Kajian Etnolinguistik).” Lokabasa 7 (1): 94-102.

Hasidah, M., Dan D. W. Rousdy. 2017. "Kandungan Pigmen Klorofil, Karotenoid Dan Antosianin Pada Daun Caladium.” Jurnal Protobiont 6 (2): 1-8.

Hendriyani, Ika Susanti, Dan Nintya Setiari. 2009. "Kandungan Klorofil Dan Pertumbuhan Kacang Panjang (Vigna Sinensis) Pada Tingkat Penyediaan Air Yang Berbeda." Jurnal Sains \& Matematika 17 (3): 145-50.

Ignatius, Hadianto, Dan Ahmad Riduan. 2014. "Respon Tanaman Terung (Solanum Melongena L.) Terhadap Pemberian Pupuk Organik Cair Urine Sapi.” Jurnal Penelitian Universitas Jambi: Seri Sains $16(1)$.

Kasi, Pauline Destinugrainy, Suaedi Suaedi, Dan Faridha Angraeni. 2018. "Pemanfaatan Pupuk Organik Cair Rebung Bambu U Ntuk Pertumbuhan Kangkung Secara Hidroponik." Biosel: Biology Science And Education 7 (1): 42-48.

Krisnawati, Susi, Maria Theresia Darini, Dan Darnawi Darnawi. 2019. "Pengaruh Komposisi Media Tanam Dan Dosis Pupuk Kascing Terhadap Pertumbuhan Dan Hasil Tanaman Tomatvarietas Intan (Solanum Lycopersicum L.).” Jurnal Ilmiah Agroust 2 (1): 43-55.

Latifah, Sofia, Ratnawati Ratnawati, Dan Lili Sugiyarto. 2017. "Pengaruh Variasi Konsentrasi Pupuk Organik Terhadap Produktivitas Tanaman Tomat Dengan Pemaparan Gelombang Suara." Biologi-S1 6 (1): 9-19. 
Lestari, Bibit Lilik. 2011. "Kajian Zpt Atonik Dalam Berbagai Konsentrasi Dan Interval Penyemprotan Terhadap Produktivitas Tanaman Bawang Merah (Allium Ascolanicum L.)." Rekayasa 4 (1): 33-37.

Maong, Reynal, Johnly Alfreds Rorong, Dan Feti Fatimah. 2016. “Aktivitas Ekstrak Buah Tomat (Lycopersicum Esculentum Mill) Sebagai Penstabil Oksigen Singlet Dalam Reaksi Fotooksidasi Asam Linoleat." Jurnal" Mipa" Unsrat Online 5 (1): 60-64.

Marti, Ni Wayan. 2012. "Pengembangan Aplikasi Multimedia Interaktif Pembudidayaan Tanaman Tomat." Jurnal Pendidikan Teknologi Dan Kejuruan 7 (1).

Mudya, Rista Wahyu. 2019. "Aplikasi Pupuk Organik Cair Dari Kulit Pisang Kepok (Musa Paradisiaca L.) Terhadap Pertumbuhan Tanaman Cabai Merah (Capsicum Annuum L.).”

Nathania, Benita, I. Made Sukewijaya, Dan Ni Wayan Sri Sutari. 2012. "Pengaruh Aplikasi Biourin Gajah Terhadap Pertumbuhan Dan Hasil Tanaman Sawi Hijau (Brassica Juncea L.)." E-Jurnal Agroekoteknologi Tropika (Journal Of Tropical Agroecotechnology).

Novalina, Novalina, Wilyus Wilyus, Hanibal Hanibal, Dan Sakrani Sakrani. 2019. "Potensi Pupuk Organik Cair Yang Mengandung Mikroorganisme Lokal Sebagai Biopestisida Terhadap Serangga Hama Pada Tanaman Padi (Oryza Sativa L)." Dalam Seminar Nasional Pembangunan Pertanian Berkelanjutan Berbasis Sumber Daya Lokal, 278-87.

Parman, Sarjana. 2007. "Pengaruh Pemberian Pupuk Organik Cair Terhadap Pertumbuhan Dan Produksi Kentang (Solanum Tuberosum L.).” Anatomi Fisiologi 15 (2): 21-31.

Puspaningrum, Dylla Hanggaeni Dyah, Dan Ni Luh Utari Sumadewi. T.T. "Extraction And Identification Of Oligosaccharides In Tabah Bamboo Shoots Flour Extract (Gigantochloa Nigrociliata Buse-Kurz) As Prebiotic Source." Media Ilmiah Teknologi Pangan (Scientific Journal Of Food Technology) 4 (2): 148-56.

Rosmaiti, Rosmaiti, Dan Juliandi Juliandi. 2016. "Peningkatan Pertumbuhan Dan Produksi Kacang Tanah (Arachis Hypogaea, L.) Dengan Pemberian Mikro Organisme Lokal (Mol) Dan Pembumbunan.” Jurnal Penelitian Agrosamudra 3 (2): 8-18.

Samosir, Abdullah. 2014. "Pengaruh Mol Rebung Bambu Terhadap Pertumbuhan Bibit Kelapa Sawit (Elaeis Guineensis Jacq) Di Pre Nursery." Bioplantae 3 (1): 8-16.

Setiawan, Alfian Bagus. 2019. "Efektivitas Pemberian Pupuk Organik Cair Yang Berasal Dari Tiga Jenis Rebung Bambu Terhadap Pertumbuhan Tanaman Tomat (Solanum Lycopersicum Mill.)."

Sihombing, Rina Febriyati, Dan Riris Aryawaty. 2013. "Kandungan Klorofil-A Fitoplankton Di Sekitar Perairan Desa Sungsang Kabupaten Banyuasin Provinsi Sumatera Selatan.” Maspari Journal 5 (1): 34-39.

Subandi, Muhammad, Nella Purnama Salam, Dan Budy Frasetya. 2015. "Pengaruh Berbagai Nilai Ec (Electrical Conductivity) Terhadap Pertumbuhan Dan Hasil Bayam (Amaranthus Sp.) Pada Hidroponik Sistem Rakit Apung (Floating Hydroponics System).” Jurnal Istek 9 (2).

Sudjana, Briljan. 2015. "Pengunaan Azolla Untuk Pertanian Berkelanjutan.” Majalah Ilmiah Solusi 1 (02). 
Thana, Dwi Prasetyawati. 2017. "Efektivitas Berbagai Jenis Zpt Alami Terhadap Perkecambahan Dan Pertumbuhan Bibit Markisa Ungu (Passiflora Edulis).” Agrosaint 8 (2): 98-102.

Walida, Hilwa, Eko Surahman, Fitra Syawal Harahap, Dan Wiwit Arif Mahardika. 2019. "Response Of Giving Local Microorganism Solutions From Bamboo Shoot To Growth And Production Of Red Chili Plant (Capsicum Annum L) Jenggo F1." Jurnal Pertanian Tropik (Indonesian Tropical Agriculture Journal) Accredited By Kemenristek Dikti No: 21/E/Kpt/2018 6 (3, Dec): 424-29.

Wasonowati, Catur. 2011. "Meningkatkan Pertumbuhan Tanaman Tomat (Lycopersicon Esculentum) Dengan Sistem Budidaya Hidroponik.” Agrovigor: Jurnal Agroekoteknologi 4 (1): 21-27.

Zulfiah, Naila, Dan Aisyah Aisyah. 2016. "Status Trofik Perairan Rawa Pening Ditinjau Dari Kandungan Unsur Hara (No3 Dan Po4) Serta Klorofil-A.” Bawal Widya Riset Perikanan Tangkap 5 (3): 189-99. 
